\title{
A diabeteses cardialis autonóm neuropathia diagnosztikája
}

\author{
Sztanek Ferenc dr. ${ }^{1}$ - Jebelovszki Éva dr. ${ }^{2}$ \\ Gaszner Balázs dr. ${ }^{3}$ - Zrínyi Miklós ${ }^{4}$ \\ Páll Dénes dr. ${ }^{4}$ - Kempler Péter dr. ${ }^{5}$ - Harangi Mariann dr. ${ }^{1}$ \\ ${ }^{1}$ Debreceni Egyetem, Általános Orvostudományi Kar, Anyagesere Betegségek Tanszék, \\ Belgyógyászati Intézet, Debrecen \\ ${ }^{2}$ Szegedi Tudományegyetem, Általános Orvostudományi Kar, \\ II. Belgyógyászati Klinika és Kardiológiai Központ, Szeged \\ ${ }^{3}$ Pécsi Tudományegyetem, Általános Orvostudományi Kar, Szívgyógyászati Klinika, Pécs \\ ${ }^{4}$ Debreceni Egyetem, Általános Orvostudományi Kar, Gyógyszerfejlesztési Koordinációs Központ, Debrecen \\ ${ }^{5}$ Semmelweis Egyetem, Általános Orvostudományi Kar, I. Belgyógyászati Klinika, Budapest
}

\begin{abstract}
A cardialis autonóm neuropathia (CAN) az 1-es és 2-es típusú diabetes mellitus gyakori szövődménye, melyet a cardiovascularis rendszer autonóm szabályozásának zavaraként definiálnak. A CAN szoros összefüggést mutat a halálozási adatokkal, és bizonyos vizsgálatok szerint a vascularis szövődmények, köztük a stroke, a koszorúér-betegség és a szívinfarktus okozta halálozással is. Korai stádiumban a CAN tünetmentes lehet, majd a betegség előrehaladtával megjelennek a klinikai tünetek is. A tünetmentes periódusban a cardiovascularis reflextesztek segítségével azonosítható, melyek prognosztikai értékkel is bírnak. A tünetek megjelenését követően az autonóm múködési zavar a nyugalmi tachycardia, csökkent fizikai terhelhetőség, ortosztatikus hipotónia, syncope, intraoperatív cardiovascularis instabilitás, néma szívizominfarktus vagy ischaemia okozta megnövekedett halálozás alapján diagnosztizálható. Bár a CAN nagyon gyakori és előrehaladott esetekben súlyos diabeteses szövődmény, gyakran nem kerül felismerésre. Mivel a betegség korai stádiumában a cardiovascularis denerváció részlegesen visszafordítható, vagy progressziója lelassítható, a legújabb irányelvek határozottan ajánlják a CAN szürését diabeteses betegekben. Az alábbiakban összefoglaljuk a diabeteses CAN szürésére alkalmas diagnosztikai lehetőségeket.

Orv Hetil. 2019; 160(35): 1366-1375.
\end{abstract}

Kulcsszavak: diabetes mellitus, cardialis autonóm neuropathia, cardiovascularis reflexteszt, szívfrekvencia-variabilitás, kérdőív

\section{Diagnosis of diabetic cardiac autonomic neuropathy}

Cardiac autonomic neuropathy (CAN) is a common complication in type 1 and 2 diabetes and is defined as the impairment of autonomic control of the cardiovascular system. CAN is strongly associated with increased mortality, and in some studies with morbidity of vascular complications, such as stroke, coronary artery disease and myocardial infarction. At the early stages, CAN can be subclinical and it becomes clinically evident as the disease progresses. Subclinically, the disease is defined by cardiovascular reflex testing, which may have prognostic implications. Clinically, the impairment in autonomic function is associated with resting tachycardia, exercise intolerance, orthostatic hypotension, syncope, intraoperative cardiovascular instability, silent myocardial infarction and ischemia, and increased mortality. Although very common and serious, CAN is a frequently overlooked complication of diabetes. Because the progression of cardiovascular denervation is partly reversible or can be slowed down in the early stages of the disease, recent guidelines strongly recommend screening for CAN in patients with diabetes. In this review we summarize the diagnostic tools suggested in the screening for diabetic CAN.

Keywords: diabetes mellitus, cardiac autonomic neuropathy, cardiovascular reflex test, heart-rate variability, questionnaire

Sztanek F, Jebelovszki É, Gaszner B, Zrínyi M, Páll D, Kempler P, Harangi M. [Diagnosis of diabetic cardiac autonomic neuropathy]. Orv Hetil. 2019; 160(35): 1366-1375.

(Beérkezett: 2019. március 26.; elfogadva: 2019. április 24.) 


\section{Rövidítések}

$\mathrm{ADA}=$ (American Diabetes Association) Amerikai Diabetes Társaság; ASP = Autonomic Symptom Profile questionnaire; AUC $=$ (area under the curve $)$ görbe alatti terület; CAN $=($ cardiac autonomic neuropathy) cardialis autonóm neuropathia; CASS $=$ Composite Autonomic Scoring Scale; COMPASS = Composite Autonomic Symptom Scale; CI = (confidence interval) konfidenciaintervallum; DAN $=$ (diabetic autonomic neuropathy) diabeteses autonóm neuropathia; DCCT $=$ Diabetes Control and Complications Trial; $\mathrm{DM}=$ (diabetes mellitus) cukorbetegség; $\mathrm{DN}=$ (diabetic neuropathy) diabeteses neuropathia; DSPN = (distal symmetric polyneuropathy $)$ distalis szimmetrikus polyneuropathia; EDIC = Epidemiology of Diabetes Interventions and Complications; $\mathrm{EKG}=($ electrocardiography) elektrokardiográfia; PET $=$ (positron emission tomography) pozitronemissziós tomográfia; $\mathrm{ROC}=$ (receiver operating characteristic [curve]) a vevőegység operációs karakterisztikus (görbéje); SPECT $=$ (single photon emission computed tomography) egyfoton-emissziós komputertomográfia

A diabetes mellitus (DM) több mint 450 millió embert érint világszerte, ami a népesség $\mathrm{kb}$. 8,5\%-ának felel meg. Sajnos nem rendelkezünk pontos prevalenciaadatokkal az abszolút inzulinhiánnyal jellemezhető l-es típusú és a föleg inzulinrezisztenciával összefüggő 2 -es típusú cukorbetegségről külön-külön, azonban mindkét betegség előfordulása világszerte növekszik. A 2-es típusú cukorbetegség jóval gyakoribb, az esetek $85-90 \%$-át teszi ki [1]. A cukorbetegségben kialakuló késői kis- és nagyérszövődmények csaknem minden szervet érintenek, ami csökkent életminőséget okoz, és korai halálozáshoz vezet. A diabeteses neuropathia (DN) a leggyakrabban elóforduló és a legkorábban diagnosztizálható krónikus microvascularis szövődmény cukorbetegségben, azonban a változatos klinikai megjelenés és a sokszor nem típusos tünetek miatt csak későn kerül felismerésre. Kialakulásának oka intenzív kutatások tárgyát képezi, a lehetséges okok között a hyperglykaemia okozta fehérjeglikáció mellett az oxidatív stressz, a poliolútvonal hiperaktivitása, haemostaseologiai és rheologiai változások, autoimmun és egyéb gyulladásos folyamatok is szerepelnek $[2,3]$. Az idegi károsodások korai felismerése a diabeteses betegek szempontjából kiemelkedő fontosságú, hiszen a distalis szimmetrikus polyneuropathia (DSPN) kezelésében számos terápiás lehetőség áll rendelkezésünkre [4]. A DN progressziója a betegek több mint 50\%-ánál tünetszegény vagy aszimptomatikus lehet, ezért nem kerül időben felismerésre ez a szövődmény, így a nem megfelelöen beállított szénhidrátháztartás mellett késik a megfelelő gyógyszeres terápia; továbbá nem alkalmaznak megelőző lábápolást, ezáltal nő az érzéskiesésből adódó lábsérülések és fekélyek kialakulásának kockázata. A diabeteses autonóm neuropathia (DAN), a szimpatikus és/vagy a paraszimpatikus vegetatív idegrostok károsodásának felismerése és kezelése jelentôsen csökkentheti a cardiovascularis kockázatot, és javítja az életminőséget [5]. Változatos tünetekkel járhat, többek között nyugalmi tachycardia, ortosztatikus hipotenzió, tünetmentes hypoglykaemiák, a gyomor- és bélmotilitás változása (gastroparesis, hasmenés, székrekedés), a húgyhólyagfunkció zavara [6], sudomotoros funkciózavar és a pupillomotoros rendszer múködési rendellenessége észlelhető [7]. Klinikai szempontból a legjelentősebb és leggyakrabban vizsgált a cardialis autonóm neuropathia (CAN), melynek előfordulása még igen alacsony l-es típusú diabetesben a diagnózis megállapításakor, viszont a DCCT/EDIC alvizsgálata alapján 20 éves betegségtartam után a prevalenciája $30 \%$ körüli [8]. A 2-es típusú cukorbetegség felfedezésekor az autonóm funkciók károsodása is gyakran igazolható, 15 éves betegségtartam esetén a betegek 65-73\%-ában kimutatható, szoros összefüggésben a szénhidrátháztartás állapotával és a hemoglobin $A_{1 c}$ szintjével $[9,10]$. Egyes vizsgálatok megerősítették, hogy a CAN már praediabetesben is kialakulhat, különösen a csökkent glükóztolerancia és az emelkedett éhgyomri vércukorérték együttes előfordulásával járó esetekben, amelyekben a prevalenciát 11,4\%-osnak találták [11]. A CAN jelenléte mind 1-es, mind 2-es típusú cukorbetegségben a jövőbeli szív- és érrendszeri betegségek előfordulásának kockázati tényezője, ezért korai diagnosztikája jelentős szerepet játszhat a fó cardiovascularis események, mint a szívizominfarktus, a stroke és a szívelégtelenség megelőzése szempontjából $[12,13]$.

A cardiovascularis megbetegedések kialakulásának kockázata akár négyszer nagyobb lehet diabeteses betegekben, mint a nem diabeteses populációban. Ennek hátterében a dyslipidaemia, a hipertónia és a krónikus vesebetegség gyakoribb előfordulása mellett a CAN kialakulása állhat [14]. Bár a CAN a cukorbetegség gyakori szövődménye, gyakran nem kerül felismerésre. Ugyanakkor az idóben felállított diagnózisnak fontos klinikai jelentősége lehet, hiszen a CAN a cardiovascularis halálozás független rizikófaktora, jelenlétében gyakrabban fordul elő a tünetmentes szívizom-ischaemia, nő az aritmiahajlam és a fó cardiovascularis események kialakulásának kockázata [15].

\section{A diabeteses CAN definíciója}

A jelenleg érvényes definíciót a Toronto Konszenzus Panel állította fel. Ennek alapján diabeteses CAN-ról beszélünk a cardialis autonóm szabályozás zavara esetén, ha a beteg diabeteses, és az autonóm neuropathia egyéb okai kizárhatók [16]. A definíció tehát a cardialis autonóm szabályozás részletes vizsgálatát feltételezi, ám a mindennapi orvosi gyakorlatban ez még a jellegzetes tünetek megjelenése esetén sem történik meg minden esetben, pedig a diagnózis hiányában a megfelelő kezelés is elmaradhat. Ennek egyik oka az, hogy a kezelőorvos nem gondol a CAN kialakulásának lehetőségére, illetve a tüneteket más társbetegségeknek tulajdonítja. Az eszközös diagnosztikai lehetőségek számos helyen nem vagy csak nehezen érhetők el. 


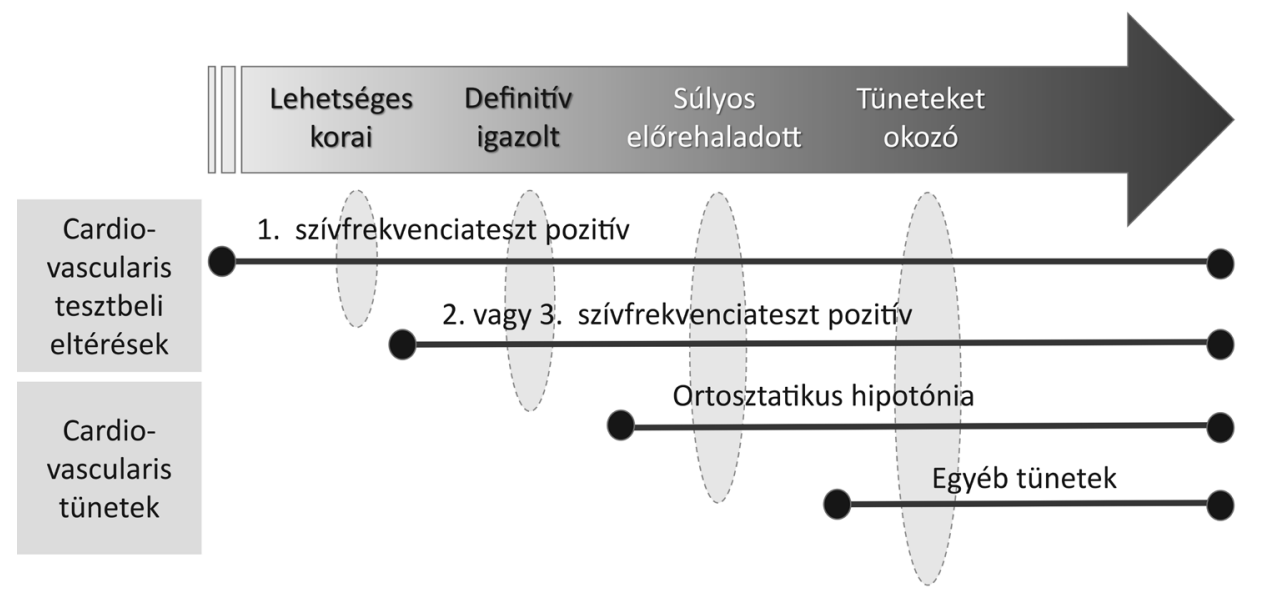

\section{A diabeteses CAN jellegzetességei}

A CAN kezdetben nem okoz klinikai tüneteket, csak a cardiovascularis reflextesztek jelezhetik kialakulásának korai fázisát. Az idegi károsodás előrehaladtával azonban súlyosbodik az autonóm idegrendszer szabályozási zavara, ami számos jellegzetes tünet és panasz megjelenésével jár [10] (1. ábra).

$\mathrm{Az}$ autonóm neuropathia kialakulásában jelentős szerepet játszik a paraszimpatikus funkciózavar, mely a szívfrekvencia jelentôs emelkedését okozza. A vegetatív denerváció aszcendáló jellegú, és hosszfüggő módon alakul ki, ezért első́ként általában a nervus vagus érintettsége észlelhetô, ami szimpatikus túlsúlyt eredményez. Mivel kezdetben a baroreceptorok múködése gátolt, az első jel a szívfrekvencia-variabilitás beszúkülése, illetve megszünése, majd a sympathicotonus egyre kifejezettebbé válása miatt megjelenik a nyugalmi tachycardia (akár 90-130/ perc). A belégzési teszt során észlelt fixált szívfrekvencia, azaz a frekvenciaváltozás elmaradása már teljes cardialis denervációt, azaz a folyamat előrehaladott voltát jelzi [17]. A paraszimpatikus denerváció, a szívfrekvencia és a vérnyomás variabilitásának beszúkülése a fizikai terhelhetőség csökkentését idézi elő, mivel a szív teljesítménye nem képes alkalmazkodni a fokozott igényhez. Emellett CAN esetén a fizikai terhelés során az elért szívfrekvencia alkalmatlan a teljesítmény jellemzésére, ezért fokozott odafigyelés szükséges a CAN-ban szenvedő betegek terhelésekor.

Gyakori tünet az ortosztatikus hipotónia, vagyis az alacsony vérnyomás kialakulása álló testhelyzetben [18]. $\mathrm{Az}$ ortosztatikus vérnyomásesés oka cukorbetegségben a perifériás kisvénák szimpatikus beidegződésének károsodása és a vasoconstrictio csökkenése, aminek következtében felálláskor elmarad a vérnyomás kompenzatorikus emelkedése. Az ortosztatikus hipotóniát hagyományosan a Schellong-teszt segítségével állapíthatjuk meg, ha a szisztolés vérnyomás esése nagyobb, mint $20 \mathrm{Hgmm}$, vagy ha a diasztolés vérnyomás esése a $10 \mathrm{Hgmm}$ - $t$ meghaladja fekvő, majd álló testhelyzetben 3 perc elteltével mérve. Jellegzetes eltérés továbbá a vérnyomás fiziológiás csökkenésének elmaradása az éjszakai órákban (nondipper jelenség) vagy akár az éjszakai órákban mért magasabb vérnyomásértékek.

Az elektrokardiográfián (EKG) észlelt QT-távolság megnyúlása és a QT-diszperzió növekedése az aritmiahajlam fokozásán keresztül a malignus ritmuszavarok, így a hirtelen szívhalál kialakulásának kockázatát növeli [19]. Hátterében a szimpatikus innerváció károsodása mellett hypoglykaemia is állhat. A néma szívizom-ischaemia esetén a szívizom oxigénhiánya okozta jellegzetes anginás panaszok, azaz a szorító, nyomó mellkasi fájdalom nem alakul ki. Ennek oka teljesen nem tisztázott, de az autonóm beidegzés zavara és a fájdalomküszöb eltolódása biztosan szerepet játszik a megjelenésében. A CAN-ban szenvedő betegek esetén az intra- és perioperatív szövődmények kialakulása és a halálozási arány is emelkedett a hemodinamikai instabilitás miatt. Gyakoribb az intraoperatív hipotónia, mivel az altatószerek adására nem alakul ki vasoconstrictiós válaszreakció. Elöfordulhat súlyos intraoperatív hypothermia kialakulása is.

A legfontosabb klinikai tüneteket a 1. táblázat foglalja össze.

1. táblázat |A cardialis autonóm neuropathia legfontosabb tünetei

A szívfrekvencia változásai

- Csökkent szívfrekvencia-variabilitás

- Nyugalmi tachycardia

- Fixált szívfrekvencia fizikai terhelés során

A vérnyomás változásai

- Éjszakai hipertónia

- Ortosztatikus hipotónia

- Posztprandiális hipotónia

Csökkent fizikai terhelhetőség

Néma szívizom-ischaemia

Intra- és perioperatív cardiovascularis instabilitás

QTc-megnyúlás 


\section{Diagnosztikai lehetőségek diabeteses CAN esetén}

A NEURODIAB-munkacsoport ajánlása szerint minden 2 -es típusú cukorbetegnél a diagnózis felállításakor, l-es típusúaknál a diagnózist követő 5 év múlva a CAN felismerése céljából szứrővizsgálatot javasolt végezni, főlleg a rossz anyagcserekontrollal összefüggő magas cardiovascularis kockázat esetén, ha DSPN-re típusos panaszok is fennállnak, illetve egyéb macro- és microvascularis szövődmény jelenléte esetén [16]. Az ADA 2017-ben kiadott iránymutatása szerint az autonóm neuropathia irányú vizsgálatok javasoltak igazolt diabeteses microvascularis komplikáció és DSPN-re jellemző panaszok esetén, valamint olyan cukorbetegeknél, akiknek meg nem érzett hypoglykaemiák szerepelnek az anamnézisükben [5].

A CAN diagnosztikája a klinikai tünetek felismerése mellett noninvazív eszközös és kérdőívekkel történő vizsgálatok elvégzésén alapul, melyek egyike sem alkalmas tökéletesen a mindennapi klinikai gyakorlatban történő alkalmazásra, ezért az elmúlt évtizedekben számos újabb vizsgálómódszert teszteltek és javasoltak a CAN szúrésére. Mivel a CAN az autonóm neuropathia (AN) része, a CAN diagnosztikájában használatos módszerek mellett részben érintjük a DAN diagnosztikai spektrumát is (például a sudomotoros funkció vizsgálata) és a kérdő́ives módszereket, amelyeket a DAN felismerése érdekében fejlesztettek ki, de indirekt módon szerepet játszanak a CAN felismerésében.

\section{Cardiovascularis reflextesztek}

A cardiovascularis reflextesztek a mai napig alapvető módszernek számítanak a klinikai gyakorlatban, mivel a diagnózis felállításának jól standardizált, nem invazív és biztonságos módját nyújtják. A cardialis autonóm reflexteszteket 1980-ban Ewing írta le mint a CAN diagnosztikájának eszközét; a Toronto Konszenzus Panel irányelve alapján legalább két kóros teszt esetén biztos, egy kóros teszt esetén lehetséges a CAN jelenléte [20]. Ortosztatikus hipotónia és két vagy több kóros teszt együttes fennállása előrehaladott CAN jelenlétét jelezheti. A mindennapi gyakorlatban a Ewing-tesztek elvégzésével az autonóm idegrendszer károsodását nemzetközileg is elfogadott pontrendszer alapján ítélhetjük meg, és a pontokat összesítve az CAN súlyossága az enyhe, kifejezett és súlyos fokozatokba sorolható [21].

Az öt reflexteszten belül két nagy csoportot különíthetünk el. A paraszimpatikus beidegzés múködését a mélylégzéses vizsgálat, a Valsalva-manőver és a fekvésből hirtelen felálláskor bekövetkező szívfrekvencia-változás mérésével értékelhetjük. A fekvésből való felálláskor és a kézizomszorító erő vizsgálatakor (handgrip test) mért vérnyomásértékek alakulása elsősorban a szimpatikus idegrendszer múködéséról nyújthat számunkra tájékoz- tatást. A mélylégzés során a légzési aritmia jelenlétét vizsgáljuk, mely egészségesekben állandóan változó szívfrekvenciát jelent nyugalmi helyzetben a légzéssel összefüggésben: belégzés során gyorsul, kilégzéskor lassul a szívmúködés. A légzési aritmia csökkenése, illetve megszűnése autonóm neuropathia fennállására utalhat. A Valsalva-manőver elvégzésekor standardizált ellenállással szemben végzett erőltetett kilégzés hatására bekövetkező szívfrekvencia-változásokat vizsgálunk. Normális esetben a manőver kezdetén a vérnyomás csökken, és a szívfrekvencia emelkedik, majd a vizsgálat végén a vérnyomás a kiindulási érték fölé emelkedik, és ez a szívfrekvencia csökkenéséhez vezet. A vizsgálat során EKGmonitorozás történik, és a Valsalva-hányadost a manőver után mért leghosszabb és legrövidebb RR-távolságok hányadosa adja. A felállást közvetlenül kísérő szívfrekvencia-változások követésével az ún. $30: 15$ hányadost határozhatjuk meg, melynek során a beteg nyugodt állapotban, fekvő helyzetből feláll, és álló helyzetben marad folyamatos EKG-monitorozás mellett. Élettani körülmények között felálláskor átmenetileg gyorsul, majd lassul a szívfrekvencia. A frekvenciaemelkedés maximumát a 15. ütés körül, a lassulás maximumát a 30 . szívütés körül éri el. Az ezeknél az ütéseknél mért maximális és minimális RR-távolság hányadosa adja a vizsgálat eredményét. A fekvő helyzetből való felállást kísérő szisztolés vérnyomásértékek változásának vizsgálata során a nyugalmi állapot 5. percében, majd a felállást követő 1,5 és 10 perc múlva vérnyomásmérés történik. Diabeteses betegekben autonóm neuropathia esetén nagymértékú vérnyomásesés, ortosztatikus hipotenzió észlelhető, melyek hátterében a perifériás erek szimpatikus innervációjának károsodása és a vasoconstrictio elmaradása áll. A tartós kézizomfeszítést kísérő diasztolés vérnyomásváltozások értékelése során egy szenzor szorítása mellett az ellentétes karon percenként vérnyomásmérés történik, és a diasztolés vérnyomásértékeket regisztráljuk. Normálesetben a kézizmok feszítésére a szívfrekvencia és a szisztémás vérnyomás emelkedése következik be. Szimpatikus károsodásra utal, ha a reflexválasz elmarad [22, 23]. Megjegyzendő, hogy a kézizomfeszítési (handgrip) teszt használatát ma már túlhaladottnak tekintik, mivel a vérnyomáscsökkentő kezelés és a kiindulási diasztolés vérnyomásérték erősen befolyásolja a kapott eredményt [23].

A cardialis autonóm reflexteszteket a 2. táblázat foglalja össze [24]. Az első három reflexteszt esetén a határértékek korfüggőek. A jelölt értékek a normális referenciatartomány két szélső értékét jelzik. A vérnyomásválaszt vizsgáló tesztekben korfüggést nem tapasztaltak. A diagnosztikai érték oszlopában feltüntetett specificitás, szenzitivitás és esélyhányados $(95 \% \mathrm{CI})$ az adott tesz hatékonyságát jelzi a teljes vizsgálati tesztsor elvégzéséhez képest [24]. 
2. táblázat A cardialis autonóm reflextesztek (Ewing-tesztek)

\begin{tabular}{|c|c|c|c|c|c|}
\hline A teszt neve & Mit értékel? & $\begin{array}{l}\text { Az autonóm } \\
\text { idegrendszer mely } \\
\text { részét vizsgálja? }\end{array}$ & Értelmezése & $\begin{array}{l}\text { Határértéke } \\
\text { (korfüggő) }\end{array}$ & $\begin{array}{l}\text { Diagnosztikai értéke } \\
\text { (specificitás }=\mathrm{Sp} \\
\text { szenzitivitás }=\mathrm{Sz} \text { ) }\end{array}$ \\
\hline $\begin{array}{l}\text { Mély belégzés során } \\
\text { kialakult szívfrekvencia- } \\
\text { változás (kilégzés : } \\
\text { belégzés = E : I) }\end{array}$ & $\begin{array}{l}\text { A szívfrekvencia } \\
\text { variabilitása ütésról } \\
\text { ütésre mély belégzés } \\
\text { során (R-R } \\
\text { variabilitás) }\end{array}$ & $\begin{array}{l}\text { A paraszimpatikus } \\
\text { aktivitás károsodását } \\
\text { vizsgálja a nervus } \\
\text { vagus szívfrekvenciát } \\
\text { csökkentő hatásán } \\
\text { keresztül }\end{array}$ & $\begin{array}{l}\text { Az E : I arány: a } \\
\text { leghosszabb R-R } \\
\text { távolsága a kilégzés } \\
\text { során osztva a } \\
\text { legrövidebb R-R } \\
\text { távolsággal a belégzés } \\
\text { során }\end{array}$ & $\begin{array}{l}1,22-1,1 \\
\text { (15-65 év) }\end{array}$ & $\begin{array}{l}\text { Sp: } 19 \% \\
\text { Sz: } 98 \% \\
p=0,115 \\
\text { OR }(95 \% \mathrm{CI})=2,34 \\
(1,19-4,77)\end{array}$ \\
\hline $\begin{array}{l}\text { A szívfrekvencia } \\
\text { változása álló testhelyzet- } \\
\text { ben }(30: 15 \text { arány) }\end{array}$ & $\begin{array}{l}\text { A szívfrekvencia } \\
\text { variabilitása ütésről } \\
\text { ütésre álló testhely- } \\
\text { zetben (R-R } \\
\text { variabilitás) }\end{array}$ & $\begin{array}{l}\text { A paraszimpatikus } \\
\text { aktivitás károsodását } \\
\text { vizsgálja a nervus } \\
\text { vagus szívfrekvenciát } \\
\text { csökkentő hatásán } \\
\text { keresztül }\end{array}$ & $\begin{array}{l}\text { A } 30 \text { : } 15 \text { arány: az } \\
\text { R-R távolság a } 30 \text {-dik } \\
\text { szívverésnél osztva az } \\
\text { R-R távolsággal a } 15 . \\
\text { szívverésnél }\end{array}$ & $\begin{array}{l}1,17-1,06 \\
\text { (15-65 év) }\end{array}$ & $\begin{array}{l}\text { Sp: } 96 \% \\
\text { Sz: } 65 \% \\
\text { p<0,001 } \\
\text { OR }(95 \% \text { CI })=44,07 \\
(12,68-153,25)\end{array}$ \\
\hline $\begin{array}{l}\text { Valsalva-manőver } \\
\text { (Valsalva-arány) }\end{array}$ & $\begin{array}{l}\text { A szívfrekvencia- } \\
\text { választ vizsgálja meg- } \\
\text { növelt mellüri és } \\
\text { hasúri nyomás alatt } \\
\text { és azt követően }\end{array}$ & $\begin{array}{l}\text { Mind a szimpatikus, } \\
\text { mind a paraszimpatikus } \\
\text { aktivitást értékeli, de } \\
\text { fóként a paraszimpati- } \\
\text { kust }\end{array}$ & $\begin{array}{l}\text { Valsalva-arány: a } \\
\text { leghosszabb R-R } \\
\text { távolság a IV. fázisban } \\
\text { osztva a legrövidebb } \\
\text { R-R távolsággal a II. } \\
\text { fázisban és a III. fázis } \\
\text { legelején }\end{array}$ & $\begin{array}{l}1,23-1,16 \\
(15-65 \text { év) }\end{array}$ & $\begin{array}{l}\text { Sp: } 62 \% \\
\text { Sz: } 92 \% \\
p=0,001 \\
\text { OR }(95 \% \mathrm{CI})=18,56 \\
(5,55-62,1)\end{array}$ \\
\hline $\begin{array}{l}\text { Vérnyomáscsökkenés álló } \\
\text { testhelyzetben (ortoszta- } \\
\text { tikus hipotenzió) }\end{array}$ & $\begin{array}{l}\text { A baroreceptor- } \\
\text { reflex vizsgálata }\end{array}$ & $\begin{array}{l}\text { A szimpatikus aktivitás } \\
\text { károsodását jelzi az } \\
\text { aktivitásra adott } \\
\text { vérnyomásválaszon } \\
\text { keresztül }\end{array}$ & $\begin{array}{l}\text { A szisztolés és } \\
\text { diasztolés vérnyomás } \\
\text { különbsége ülő és álló } \\
\text { testhelyzetben }\end{array}$ & $\begin{array}{l}20 \text { Hgmm esés a } \\
\text { szisztolés vagy } \\
10 \text { Hgmm esés } \\
\text { a diasztolés } \\
\text { vérnyomás esetén }\end{array}$ & $\begin{array}{l}\text { Sp: } 51 \% \\
\text { Sz: } 71 \% \\
p=0,061 \\
\text { OR }(95 \% \mathrm{CI})=2,5 \\
(1,28-4,88)\end{array}$ \\
\hline $\begin{array}{l}\text { A vérnyomás változása } \\
\text { tartós izomkontrakció } \\
\text { során }\end{array}$ & $\begin{array}{l}\text { A diasztolés } \\
\text { vérnyomás növeke- } \\
\text { dése az izomkont- } \\
\text { rakció következtében } \\
\text { kézi szorítóeró-méró } \\
\text { segítségével }\end{array}$ & $\begin{array}{l}\text { A szimpatikus aktivitás } \\
\text { károsodását jelzi az } \\
\text { aktivitásra adott } \\
\text { vérnyomásválaszon } \\
\text { keresztül }\end{array}$ & $\begin{array}{l}\text { A vizsgálat során mért } \\
\text { legmagasabb diasztolés } \\
\text { nyomás és a nyugalmi } \\
\text { helyzetben mért } \\
\text { diasztolés nyomások } \\
\text { átlagának különbsége }\end{array}$ & $\begin{array}{l}\text { Normál esetben } \\
>15 \mathrm{Hgmm}\end{array}$ & $\begin{array}{l}\text { Sp: } 64 \% \\
\text { Sz: } 75 \% \\
p=0,002 \\
\text { OR }(95 \% \text { CI })=5,22 \\
(1,28-4,82,6-10,558)\end{array}$ \\
\hline
\end{tabular}

\section{A szinfrekvencia-variabilitás vizsgálata}

A szívfrekvencia-variabilitás beszúkülése a cardiovascularis autonóm neuropathia korai jele, és a későbbi cardiovascularis szövődmények szempontjából prognosztikus értékű [25]. Egészségesekben a kilégzés és belégzés során a szimpatikus és paraszimpatikus idegrendszer aktivitása miatt a szívfrekvencia folyamatosan változik, míg az autonóm idegrendszer károsodásával ez a variabilitás beszúkül, majd megszúnik. A fizikális vizsgálat részeként elvégzett EKG-vizsgálat alatti mély belégzésben detektált frekvenciaeltérések önmagukban is informatívak lehetnek. A szívfrekvencia-variabilitás meghatározása emellett történhet 24 órás Holter-EKG-monitorozás vagy rövidebb időtartamú EKG-monitorozás során is. Bár a CAN és a szívfrekvencia-variabilitás beszúlkülése egyértelmúen összefügg, nincsenek egyértelmú, elfogadott értékek a diagnosztikát illetően. Nehezíti az értékelést, hogy a szívfrekvencia-variabilitást számos tényező köztük a dohányzás, a stressz, a fizikai aktivitás, az egyéb betegségek és a szedett gyógyszerek - is befolyásolja [26].
A szívfrekvencia-variabilitás meghatározása részben idő-domén analízissel, részben frekvencia-domén analízissel történhet. A teljesítményspektrum-analízis során a szívfrekvencia-variabilitást nyugalmi helyzetben vizsgálva az alacsony frekvenciájú $(0,04-0,15 \mathrm{~Hz})$ és a magas frekvenciájú $(0,15-0,4 \mathrm{~Hz})$ komponenseket vizsgálják. Az alacsony frekvenciájú komponensek a paraszimpatikus, míg a magas frekvenciájúak a szimpatikus aktivitást jellemzik [27].

\section{Szcintigráfia}

A CAN irányában elvégzett szcintigráfia a szív paraszimpatikus innervációjáról ad kvantitatív adatokat. Alkalmazható egyfoton-emissziós komputertomográfia (SPECT) és pozitronemissziós tomográfia (PET) is szimpatikus neurotranszmitter-analógok adásával (például [I123]metajodobenzil-guanidin a SPECT- és Cl1metahidroxi-efedrin a PET-vizsgálat során). A teszt noninvazív és szenzitív ugyan, azonban drága, és nem érhető el széles körben, így inkább kutatási célokat szolgál $[28,29]$. 


\section{A baroreflexek szenzitivitása}

A vérnyomás megemelkedését fiziológiás esetben a baroreceptorokon keresztül érzékeljük, melyek reflexesen növelik a vagusaktivitást, és csökkentik a szimpatikus aktivitást. Ez bradycardia, hipotenzió és perifériás vasodilatatio kialakulását okozza. A vérnyomás esésekor ezzel ellentétes folyamatok alakulnak ki. E válaszok elmaradása a baroreflexekben CAN jelenlétére utal. A vizsgálat szimpatikus aktivitást befolyásoló farmakonok használatával még érzékenyebbé tehető [25]. A baroreflextesztek eredménye jól korrelál a cardialis autonóm reflextesztek eredményeivel, és a baroreflexek károsodása a mortalitás független kockázati tényezője diabeteses betegekben [30].

\section{Szinfrekvencia-turbulencia}

A szívfrekvencia-turbulencia mérése a baroreflexek indirekt mérésére szolgáló, Holter-EKG-n alapuló módszer, és a kamrai pótütéseket követően kialakuló sinusrhythmus-fluktuáció mérésére alkalmas. A fiziológiásan gyorsuló, majd lassuló szívritmus elmaradása a baroreflexek károsodását jelzi. A módszer jelenleg nem standardizált, és nyilvánvaló hátránya, hogy a kamrai pótütések hiányában nem alkalmazható [31].

\section{A plazma katecholaminszintjének meghatározása}

A plazma noradrenalinszintjének meghatározása rutinszerúen nem ajánlott a CAN klinikai diagnózisának felállítására, bár az izom szimpatikus idegi aktivitás biokémiai mérésére alkalmas módszernek tekintik. Idiopathiás autonóm neuropathiában a noradrenalinclearance csökkent, diabeteses CAN esetén ezt nem sikerült igazolni [32].

\section{Az izom szimpatikus idegi aktivitás mérése}

A fiziológiás hyperinsulinaemiára vagy glükózbeadásra adott nagyobb nyugalmi izom szimpatikus idegi aktivitás diabeteses CAN-ban és elhízásban is leírásra került. A nyugalmi izom szimpatikus idegi aktivitás korai 2 -es típusú diabetes mellitusban többnyire inkább nagyobb, vélhetően a hyperinsulinaemia miatt, míg l-es típusú diabetesben csökkent [33]. A szimpatikus idegi válasz direkt és folyamatos módon mérhető ezzel a módszerrel, de a technika invazív, időigényes, kivitelezése speciálisan képzett személyzetet igényel, és jellegéből adódóan gyakori ismétlése nem lehetséges, ezért alkalmazása a klinikai gyakorlatban nem terjedt el [25].

\section{Az elektrokémiai börvezetés mérése}

A bőr sudomotoros funkciójának zavara a csökkent verejtékelválasztással jellemezhető [34], melynek hátterében a kis szimpatikus idegrostok károsodása áll. Az elekt- rokémiai bőrvezetés vizsgálata viszonylag egyszerúen és már korai szakaszban képes ezt kimutatni. A kapott eredmények jól korrelálnak a cardialis autonóm reflextesztek eredményeivel [35]; a módszer noninvazív, gyors, a klinikai gyakorlatban is könnyen alkalmazható, de jelenleg még csak szúkebb populáción tesztelt eljárás.

\section{Kérdöines módszerek}

A fájdalmas neuropathia vizsgálatára már évtizedek óta alkalmaznak különböző kvantitatív kérdőíves módszereket. A DSPN súlyosságának megítélésére számos fájdalomskála (például a 11 pontos Likert-skála [36]) és kérdőív (például a DN4 fájdalomdiagnosztikai kérdőív [37]) mellett jól hasznosíthatók az életminőséget felmérô módszerek is, mint a validált neuropathiaspecifikus Neuro-Qol [38] és a Norfolk Quality of Life Scale [39]. A cukorbetegek vegetatív idegrendszerének vizsgálatára megbízható és jól reprodukálható kérdőíves módszer eddig nem állt rendelkezésünkre. Korábban a Mayo Klinika munkatársai dolgoztak ki egy 169 kérdésből álló kérdőívet (Autonomic Symptom Profile questionnaire - ASP [40]), elsődlegesen klinikai vizsgálatok során az autonóm idegrendszer funkciójának értékelésére. A kérdőív 11 fő tünetcsoport szerint tartalmazza a kérdéseket, melyek alapján értékelhető az ortosztatikus hipotenzió, a secretomotoros (verejtékezéssel összefüggő) és vizeletürítési zavar, a szexuális diszfunkció, a gastroparesis, a székletürítés változása (székrekedés, hasmenés), a pupilla múködésének zavarai, a vasomotoros eltérések, a reflexsyncope, az alvási zavarok és a pszichoszomatikus eltérések. A klinikai gyakorlat számára 84 kérdésből állították össze a COMPASS-kérdőívet (Composite Autonomic Symptom Scale), melyet az autonóm funkciók értékelésére alkalmas eszközös vizsgálat (CASS - Composite Autonomic Scoring Scale [4l]) eredményével összevetve azt találták, hogy a kérdések megválaszolásával különböző betegségekben a vegetatív idegrendszer funkcionális állapota és az autonóm neuropathia súlyossága megbízható módon megítélhető lehet [40]. A COMPASS számítógépes kiértékelése azonban a mindennapi gyakorlatban bonyolultnak bizonyult, a betegek hosszadalmasnak találták a kitöltését és az adott klinikai szempontból sokszor kevésbé értékelhető és felesleges információkat. Ezért a Mayo Klinika munkatársai kidolgoztak az ASPés a COMPASS-kérdőív alapján egy 54 kérdésből álló, a gyakorlatban könnyebben alkalmazható új kérdőívet az autonóm funkciók vizsgálatára, melynek validálását nemben és életkorban illesztett 405 egészséges kontroll bevonásával végezték el [42]. Az új kérdőív a Likert-sémához hasonlóan 1-től 7-ig terjedő skálát alkalmaz, és az autonóm tünetcsoportok jelenlétére vagy hiányára, súlyosságára kérdez rá. A teszt megbízhatóságát a Cronbach- $\alpha$ koefficiens kiszámításával igazolták, mely megbízhatósági mutató a skála belső konzisztenciáját fejezi ki egy 0 és 1 közötti számmal, értékét 0,7-0,85 között tartjuk elfogadhatónak: ez alatt nem tekinthető 
konzisztensnek a skála, fölötte viszont már redundáns, fölösleges többletinformációkat is tartalmaz.

A Cronbach- $\alpha$ koefficiens a korábbi COMPASS-kérdőív esetén -0,89-0,79 között volt, és csak az ortosztatikus keringésváltozásra és a szexuális (erectilis) diszfunkcióra vonatkozó kérdések esetén volt az érték 0,7-nél magasabb. Az új, 54 kérdéses teszt pontrendszerénél a Cronbach- $\alpha$ koefficiens 0,4-0,9 közöttinek bizonyult, az összes vizsgált tünetcsoport esetén felülmúlta a korábbi kérdőívnél számított értékeket, és az ortosztatikus intolerancia, funkcionális hasmenés, pupillomotoros és vasomotoros eltéréseket vizsgáló kérdések esetén 0,7

\section{COMPASS 31 teszt}

(Autonóm neuropathia szűrésére) feletti volt. Amikor a kérdéseket a vizsgált autonóm funkció szerint csoportokba rendezve végeztek feltáró faktoranalízist, a Cronbach- $\alpha$ koefficiens mind a 7 vizsgált tünetcsoport esetén (ortosztatikus hipotenzió, vasomotoros, secretomotoros, pupillomotoros eltérések, székrekedés, vizelettartási problémák és a gastroparesishasmenés tünetei gastrointestinalis diszfunkcióként közösen ) 0,71-0,93 közötti értéket mutatott. Mivel a vizsgálat redundáns többletinformációkat tartalmazott, sikerült 31 kérdésre szúlkíteni a tesztet, és a válaszokra adott pontértékek megfelelő súlyozásával a COMPASS 31-nek elnevezett kérdőív (2. ábra) megbízható mód-

1. Az elmúlt évben érzett-e szédülést közvetlenül felállás után?

1 Igen

2 Nem (ebben az esetben ugorjon az 5 . kérdésre!)

2. Felálláskor milyen gyakran észlel szédülést?
1 Néha
2 Alkalmanként
3 Gyakran
4 Majdnem mindig

3. Milyen súlyosnak ítéli meg a szédüléses tüneteket?
l Enyhének
2 Közepesnek
3 Súlyosnak

4. Az elmúlt évben ezek a szédüléses tünetek
1 jelentősen rosszabbodtak
2 valamennyire rosszabbodtak
3 körülbelül azonos szinten maradtak
4 valamennyivel javultak
5 sokat javultak
6 meg is szűntek

Név:

Telefonszám:

5. Az elmúlt évben észlelt-e karjain vagy a lábain bármilyen színváltozást (elsápadás, kipirosodás, lilaság)?
1 Igen
2 Nem (ebben az esetben ugorjon a 8. kérdésre!)

6. Melyik testtája volt érintett a színváltozásokkal kapcsolatban?
1 Karok

2 Lábak

7. Ezek a színváltozások az elmúlt évben
1 sokkal kifejezettebbek lettek
2 valamennyire kifejezettebbek lettek
3 körülbelül azonos szinten maradtak
4 valamennyire javultak
5 sokat javultak
6 el is tüntek

8. Az elmúlt öt évben észrevette-e, hogy többet vagy kevesebbet izzad?

1 Sokkal többet izzad, mint azelőtt

2 Valamennyivel többet izzad, mint azelőtt

3 Az elmúlt öt évben nem változott

4 Valamennyivel kevesebbet izzad

5 Sokkal kevesebbet izzad, mint amennyit szokott

2. ábra | A COMPASS 31 kérdő́iv magyar nyelvú változatának első oldala 
szernek bizonyult az autonóm funkciók értékelésére egészséges populáció esetén [42]. A Treister és mtsai által elvégzett érvényességi és megbízhatósági vizsgálatok szerint a COMPASS 31 belső konzisztenciája kiválónak (Cronbach- $\alpha$ koefficiens $=0,919)$, az ismételhetőség (reproduktibilitás) megfelelőnek (teszt-reteszt megbízhatóság, rs $=0,886, \mathrm{p}<0,001)$ és komparátortesztekkel összevetve a konvergens validitás is jónak bizonyult ( $\mathrm{rs}=$ $0,474, \mathrm{p}<0,001)$. A nem neuropathiás betegekkel való diagnosztikai hatékonyság összehasonlítására végzett ROC-analízis alapján a kérdőív jól hasznosítható az autonóm neuropathia vizsgálatára az érintett betegpopulációnál (görbe alatti terület $[\mathrm{AUC}]=0,749,95 \% \mathrm{CI}$ : 0,627-0,871, p = 0,01) [43]. Greco és mtsai a COMPASS 31-kérdőívet megfelelően érzékeny vizsgálati módszernek találták az autonóm neuropathia szürésére l-es és 2-es típusú diabeteses betegeknél is [44]. A kérdőív súlyozott score-értékei szignifikánsan különböztek a vizsgált diabeteses csoportban a DSPN-s és a nem neuropathiás betegek (COMPASS 31 score: $28,9 \pm 19,1$ vs. 12,7 $\pm 11,3 ; \mathrm{p}<0,0001)$ és az igazolt CAN-s és kontroll diabeteses betegek között (COMPASS 31 score: 29,9 \pm $19,5$ vs. $16,1 \pm 14,7 ; \mathrm{p}=0,003)$. A tanulmány során végzett ROC-analízis alapján CAN esetén az AUC = $0,748 \pm 0,068,95 \%$-os CI: 0,599-0,861 és DSPN esetén az AUC = 0,742 \pm 0,061, 95\%-os CI: 0,611-0,845 volt, tehát megfelelően érzékeny vizsgálati módszernek találták a diabeteses neuropathiás panaszok értékelésére. A teszt belső konzisztenciáját megfelelőnek találták (Cronbach- $\alpha$ koefficiens $=0,73)$. A súlyozott scorerendszer értékelése során 16 pont feletti határértéket határoztak meg a korai CAN valószínúségének szempontjából, ekkor a kérdőív szenzitivitása 75,0\%-nak, specificitása 64,9\%-nak, pozitív prediktív értéke 37,5\%nak és negatív prediktív értéke 90,2\%-nak bizonyult. Igazolt CAN és DSPN esetén 17 pontnál megállapítva a határt, az e feletti pontértékek esetén a teszt szenzitivitása $70,0 \%$ és $65,5 \%$, specificitása $66,7 \%$ és $79,5 \%$, pozitív prediktív értéke $25,0 \%$ és $67,9 \%$, negatív prediktív értéke 93,0\% és 77,8\% volt, ezáltal jó szűrővizsgálatnak mondható mind az autonóm funkciók megítélésére, mind a perifériás neuropathiás panaszok vizsgálatára a diabeteses betegek körében [44].

Irodalmi adatok alapján a COMPASS 31 hatékony felmérő tesztnek bizonyult az autonóm funkciók megítélésében posturalis tachycardia szindróma [45], Parkinson-kór [46], krónikus obstruktív tüdőbetegség [47] és multiplex sclerosis esetén is [48].

\section{Következtetés}

A CAN az 1-es és 2-es típusú diabetes mellitus gyakori és előrehaladott esetekben súlyos következményekkel járó szövődménye, melynek korai felismerése még akkor sem könnyű, ha gondolunk rá, és az ajánlásoknak megfelelően időben elvégezzük a javasolt szűrővizsgálatokat. A tünetek gyakran nem specifikusak, a társbetegségek miatt alkalmazott gyógyszeres kezelés a jellegzetes tüneteket elfedheti. Mivel a betegség korai stádiumában a cardiovascularis denerváció részlegesen visszafordítható, vagy progressziója lelassítható, a legújabb irányelvek határozottan ajánlják a CAN szürését diabeteses betegekben [49]. A diabeteses CAN diagnosztikájában számos lehetőség áll rendelkezésre, de ezek elvégzése többnyire időés munkaigényes, valamint a megfelelő eszközös háttér jelenlétét feltételezi. A diagnosztika a mai napig a cardialis autonóm reflextesztek elvégzésén alapul, de számos újabb eszközös és a COMPASS 31-kérdőíves módszer segíthet a korai felismerésben. Hazánkban szerencsére ma már neuropathiacentrumok állnak rendelkezésre, amelyekben a diagnosztika feltételei adottak mind a szakemberek, mind az eszközpark (neurométer, neuroteszt, cardiovascularis reflextesztek) tekintetében. Az első ilyen centrum, az Országos Neuropathia Oktató és Szűrőközpont 1998-ban jött létre Budapesten a Semmelweis Egyetem I. Belgyógyászati Klinikáján, majd ezt követően számos regionális központ és egyetemi centrum alakult meg és múködik sikeresen. A diabeteses CAN korai felismerése elősegítheti a cardiovascularis szövődmények és a korai cardiovascularis halálozás kockázatának csökkentését [49].

Anyagi támogatás: A publikáció/prezentáció/poszter elkészítését az EFOP-3.6.2-16-2017-00009. számú projekt támogatta.

Szerzői munkamegosztás: Sz. F., J. É. és G. B. a szakirodalmi adatok feldolgozásában, Z. M. és P. D. a kézirat szerkesztésében, H. M. a táblázatok elkészítésében és a kézirat összeállításában, K. P. a végső változat ellenőrzésében múködött közre. A cikk végleges változatát valamennyi szerző elolvasta és jóváhagyta.

Érdekeltségek: A szerzőknek nincsenek érdekeltségeik.

\section{Irodalom}

[1] Cho NH, Shaw JE, Karuranga S, et al. IDF Diabetes Atlas: Global estimates of diabetes prevalence for 2017 and projections for 2045. Diabetes Res Clin Pract. 2018; 138: 271-281.

[2] Sztanek F, Molnárné Molnár Á, Balogh Z. The role of oxidative stress in the development of diabetic neuropathy. [Az oxidatív stressz szerepe a diabeteses neuropathia kialakulásában.] Orv Hetil. 2016; 157: 1939-1946. [Hungarian]

[3] Winkler G, Kempler P. Pathomechanism of diabetic neuropathy: background of the pathogenesis-oriented therapy. [A neuropathia diabetica patomechanizmusa: az oki kezelés elméleti háttere.] Orv Hetil. 2010; 151: 971-981. [Hungarian]

[4] Várkonyi T, Körei A, Putz Z, et al. Advances in the management of diabetic neuropathy. Minerva Med. 2017; 108: 419-437.

[5] Pop-Busui R, Boulton AJ, Feldman EL, et al. Diabetic neuropathy: a position statement by the American Diabetes Association. Diabetes Care 2017; 40: 136-154.

[6] Barkai L, Szabó L. Urinary bladder dysfunction in diabetic children with and without subclinical cardiovascular autonomic neuropathy. Eur J Pediatr. 1993; 152: 190-192. 
[7] Pittasch D, Lobmann R, Behrens-Baumann W, et al. Pupil signs of sympathetic autonomic neuropathy in patients with type 1 diabetes. Diabetes Care 2002; 25: 1545-1550.

[8] Martin CL, Albers JW, Pop-Busui R, et al. Neuropathy and related findings in the diabetes control and complications trial/ epidemiology of diabetes interventions and complications study. Diabetes Care 2014; 37: 31-38.

[9] Low PA, Benrud-Larson LM, Sletten DM, et al. Autonomic symptoms and diabetic neuropathy: a population-based study. Diabetes Care 2004; 27: 2942-2947.

[10] Spallone V, Ziegler D, Freeman R, et al. Cardiovascular autonomic neuropathy in diabetes: clinical impact, assessment, diagnosis, and management. Diabetes Metab Res Rev. 2011; 27: 639-653.

[11] Ziegler D, Voss A, Rathmann W, et al. Increased prevalence of cardiac autonomic dysfunction at different degrees of glucose intolerance in the general population: the KORA S4 survey. Diabetologia 2015; 58: 1118-1128.

[12] Kempler P, Tesfaye S, Chaturvedi N, et al. Autonomic neuropathy is associated with increased cardiovascular risk factors: the EURODIAB IDDM Complications Study. Diabet Med. 2002; 19: 900-909.

[13] Pop-Busui R, Evans GW, Gerstein HC, et al. Effects of cardiac autonomic dysfunction on mortality risk in the Action to Control Cardiovascular Risk in Diabetes (ACCORD) trial. Diabetes Care 2010; 33: 1578-1584.

[14] Gaede P, Vedel P, Larsen N, et al. Multifactorial intervention and cardiovascular disease in patients with type 2 diabetes. $\mathrm{N}$ Engl J Med. 2003; 348: 383-393.

[15] Maser RE, Mitchell BD, Vinik AI, et al. The association between cardiovascular autonomic neuropathy and mortality in individuals with diabetes: a meta-analysis. Diabetes Care 2003; 26 : 1895-1901.

[16] Tesfaye S, Boulton AJ, Dyck PJ, et al. Diabetic neuropathies: update on definitions, diagnostic criteria, estimation of severity, and treatments. Diabetes Care 2010; 33: 2285-2293.

[17] Istenes I, Körei AE, Putz Z, et al. Heart rate variability is severely impaired among type 2 diabetic patients with hyperten sion. Diabetes Metab Res Rev. 2014; 30: 305-312.

[18] Istenes I, Keresztes K, Tündik A, et al. Blood pressure response to standing in the diagnosis of autonomic neuropathy: are initial (supine) values of importance. Diabet Med. 2007; 24: 325-327.

[19] Orosz A, Baczkó I, Nyiraty S, et al. Increased short-term beat-tobeat QT interval variability in patients with impaired glucose tolerance. Front Endocrinol. 2017; 8: 129.

[20] Ewing DJ, Campbell IW, Burt AA, et al. Vascular reflexes in diabetic autonomic neuropathy. Lancet 1973; 302: 1354-1356.

[21] Ewing DJ. Diabetic autonomic neuropathy and the heart. Diabetes Res Clin Pract. 1996; 30(Suppl) 31-36.

[22] Ewing DJ, Campbell IW, Clarke BF. Assessment of cardiovascular effects in diabetic autonomic neuropathy and prognostic implications. Ann Intern Med. 1980; 92: 308-311.

[23] Körei AE, Kempler M, Istenes I, et al. Why not to use the handgrip test in the assessment of cardiovascular autonomic neuropathy among patients with diabetes mellitus? Curr Vasc Pharmacol. 2017; 15: 66-73

[24] Fisher VL, Tahrani AA. Cardiac autonomic neuropathy in patients with diabetes mellitus: current perspectives. Diabetes Metab Syndr Obes. 2017; 10: 419-434.

[25] Bernardi L, Spallone V, Stevens M, et al. Methods of investigation for cardiac autonomic dysfunction in human research studies. Diabetes Metab Res Rev. 2011; 27: 654-664.

[26] Sammito S, Böckelmann I. New reference values of heart rate variability during ordinary daily activity. Heart Rhythm 2017; 14: 304-307.

[27] Cha SA, Park YM, Yun JS, et al. Time- and frequency-domain measures of heart rate variability predict cardiovascular outcome in patients with type 2 diabetes. Diabetes Res Clin Pract. 2018; 143: 159-169.

[28] Allman KC, Stevens MJ, Wieland DM, et al. Noninvasive assessment of cardiac diabetic neuropathy by carbon-11 hydroxyephedrine and positron emission tomography. J Am Coll Cardiol. 1993 ; 22 : 1425-1432.

[29] Mäntysaari M, Kuikka J, Mustonen J, et al. Noninvasive detection of cardiac sympathetic nervous dysfunction in diabetic patients using [123I]metaiodobenzylguanidine. Diabetes 1992; 41: 1069-1075.

[30] Gerritsen J, Dekker JM, TenVoorde BJ, et al. Impaired autonomic function is associated with increased mortality, especially in subjects with diabetes, hypertension, or a history of cardiovascular disease: the Hoorn Study. Diabetes Care 2001; 24: 17931798 .

[31] Balcioğlu S, Arslan U, Türkoğlu S, et al. Heart rate variability and heart rate turbulence in patients with type 2 diabetes mellitus with versus without cardiac autonomic neuropathy. Am J Cardiol. 2007 ; 100: 890-893.

[32] Hilsted J. Catecholamines and diabetic autonomic neuropathy. Diabet Med. 1995; 12: 296-297.

[33] Hoffman RP, Sinkey CA, Kienzle MG, et al. Muscle sympathetic nerve activity is reduced in IDDM before overt autonomic neuropathy. Diabetes 1993; 42: 375-380.

[34] Papanas N, Boulton AJ, Malik RA, et al. A simple new non-invasive sweat indicator test for the diagnosis of diabetic neuropathy. Diabet Med. 2013; 30: 525-534.

[35] He T, Wang C, Zuo A, et al. Electrochemical skin conductance may be used to screen for diabetic cardiac autonomic neuropathy in a Chinese population with diabetes. J Diabetes Res. 2017; 2017: 8289740.

[36] Backonja M, Beydoun A, Edwards KR, et al. Gabapentin for the symptomatic treatment of painful neuropathy in patients with diabetes mellitus: a randomized controlled trial. JAMA 1998; 280: 1831-1836.

[37] Spallone V, Morganti R, D'Amato C, et al. Validation of DN4 as a screening tool for neuropathic pain in painful diabetic polyneuropathy. Diabet Med. 2012; 29: 578-585.

[38] Roy MK, Kuriakose AS, Varma SK, et al. A study on comparative efficacy and cost effectiveness of pregabalin and duloxetine used in diabetic neuropathic pain. Diabetes Metab Syndr. 2017; 11: 31-35.

[39] Bouhassira D, Attal N, Alchaar H, et al. Comparison of pain syndromes associated with nervous or somatic lesions and development of a new neuropathic pain diagnostic questionnaire (DN4). Pain 2005; 114: 29-36.

[40] Suarez GA, Opfer-Gehrking TL, Offord KP, et al. The Autonomic Symptom Profile: a new instrument to assess autonomic symptoms. Neurology 1999; 52: 523-528.

[41] Low PA. Composite autonomic scoring scale for laboratory quantification of generalized autonomic failure. Mayo Clin Proc. 1993; 68: 748-752.

[42] Sletten DM, Suarez GA, Low PA, et al. COMPASS 31: a refined and abbreviated Composite Autonomic Symptom Score. Mayo Clin Proc. 2012; 87: 1196-1201.

[43] Treister R, O'Neil K, Downs HM, et al. Validation of the Composite Autonomic Symptom Scale 31 (COMPASS-31) in patients with and without small fiber polyneuropathy. Eur J Neurol. 2015 ; 22: 1124-1130.

[44] Greco C, Di Gennaro F, D'Amato C, et al. Validation of the Composite Autonomic Symptom Score 31 (COMPASS 31) for the assessment of symptoms of autonomic neuropathy in people with diabetes. Diabet Med. 2017; 34: 834-838.

[45] Rea NA, Campbell CL, Cortez MM. Quantitative assessment of autonomic symptom burden in postural tachycardia syndrome (POTS). J Neurol Sci. 2017; 377: 35-41. 
[46] Kim Y, Seok JM, Park J, et al. The composite autonomic symptom scale 31 is a useful screening tool for patients with parkinsonism. PLoS ONE 2017; 12: e0180744.

[47] Mohammed J, Derom E, De Wandele I, et al. Autonomic symptoms in patients with moderate and severe chronic obstructive pulmonary disease. Acta Clin Belg. 2018; 73: 182-190.

[48] Sander C, Hildebrandt H, Schlake HP, et al. Subjective cognitive fatigue and autonomic abnormalities in multiple sclerosis patients. Front Neurol. 2017; 8: 475.

[49] Gaede P, Vedel P, Parving HH, et al. Intensified multifactorial intervention in patients with type 2 diabetes mellitus and micro- albuminuria: the Steno type 2 randomised study. Lancet 1999; 353: 617-622.

[50] Vinik AI, Erbas T, Casellini CM. Diabetic cardiac autonomic neuropathy, inflammation and cardiovascular disease. J Diabetes Investig. 2013; 4: 4-18.

(Harangi Mariann dr., Debrecen, Nagyerdei krt. 98., 4032 e-mail: harangi@belklinika.com)

\section{"Discordia fit carior concordia." (Széthúzásnál kedvesebb az egyetértés.)}

A cikk a Creative Commons Attribution 4.0 International License (https://creativecommons.org/licenses/by/4.0/) feltételei szerint publikált Open Access közlemény, melynek szellemében a cikk bármilyen médiumban szabadon felhasználható, megosztható és újraközölhetö, feltéve, hogy az eredeti szerző és a közlés helye, illetve a CC License linkje és az esetlegesen végrehajtott módosítások feltüntetésre kerülnek. (SID_1) 